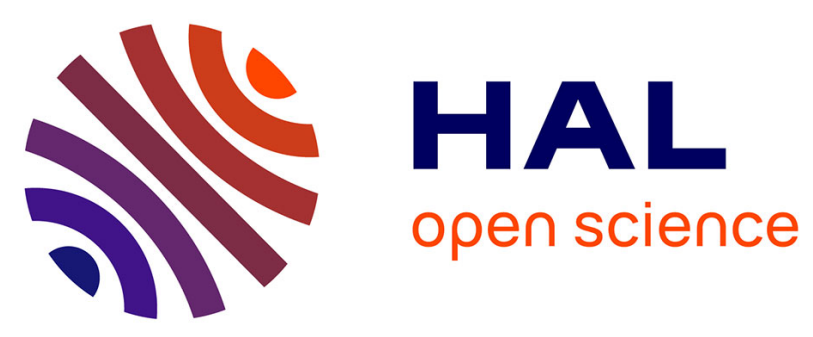

\title{
A 2-year comparative open label randomized study of efficacy and safety of etanercept and infliximab in patients with ankylosing spondylitis
}

Anna Rita Giardina, Angelo Ferrante, Francesco Ciccia, Rosalia Impastato, Maria Concetta Miceli, Alfonso Principato, Giovanni Triolo

\section{To cite this version:}

Anna Rita Giardina, Angelo Ferrante, Francesco Ciccia, Rosalia Impastato, Maria Concetta Miceli, et al.. A 2-year comparative open label randomized study of efficacy and safety of etanercept and infliximab in patients with ankylosing spondylitis. Rheumatology International, 2009, 30 (11), pp.14371440. 10.1007/s00296-009-1157-3 . hal-00562259

\section{HAL Id: hal-00562259 https://hal.science/hal-00562259}

Submitted on 3 Feb 2011

HAL is a multi-disciplinary open access archive for the deposit and dissemination of scientific research documents, whether they are published or not. The documents may come from teaching and research institutions in France or abroad, or from public or private research centers.
L'archive ouverte pluridisciplinaire HAL, est destinée au dépôt et à la diffusion de documents scientifiques de niveau recherche, publiés ou non, émanant des établissements d'enseignement et de recherche français ou étrangers, des laboratoires publics ou privés. 


\section{A two-year comparative open label randomized study of efficacy and safety of etanercept and infliximab in patients with ankylosing spondylitis.}

AnnaRita Giardina, Angelo Ferrante, Francesco Ciccia, Rosalia Impastato, Maria Concetta Miceli, Alfonso Principato, and Giovanni Triolo

Department of Internal Medicine, Division of Rheumatology, University of Palermo, Italy.

Short title: etanercept vs infliximab in ankylosing spondylitis.

Correspondence to: Professor Giovanni Triolo, Chair and Division of Rheumatology, piazza delle Cliniche 2 -90127 Palermo, Italy, FAX +39 0916552182, e-mail g.triolo@ unipa.it

Acknowledgment: AR Giardina and A Ferrante contributed equally to this work 


\begin{abstract}
The signs and symptoms of ankylosing spondylitis (AS) respond inadequately to nonsteroidal antiinflammatory drugs, corticosteroids, and disease modifying antirheumatic drugs in quite a number of patients. Tumor necrosis factor inhibitors have demonstrated to be of value in reducing AS disease activity in clinical trials. The efficacy and safety of both etanercept and infliximab in patients with ankylosing spondylitis was compared in a two-year open label randomised study. Our results are consistent with a significant more rapid clinical improvement in the infliximab treated group. Treatment with both etanercept and infliximab at the end of the study was effective, safe, and well tolerated.
\end{abstract}

Key Word 1: ankylosing spondylitis, Key Word 2: etanercept, Key Word 3: infliximab 


\section{Introduction}

Ankylosing Spondylitis (AS) is a debilitating disease predominantly affecting the spine characterised by axial skeletal ankylosis (1). Therapeutic options for AS, such as non-steroidal antiinflammatory drugs (NSAIDs), offer temporary pain relief with little if any clinical benefit on spinal mobility, and disease modifying antirheumatic drugs (DMARDs) do not appear to affect the spinal involvement of AS (2)

Tumour necrosis factor is a proinflammatory cytokine that appears to have a key role in the pathogenesis of AS inflammation (3).

Etanercept is a fully human recombinant protein, comprising two molecules of soluble TNF receptor p75 and the crystallisable fragment component of immunoglobulin G1, which specifically binds to and neutralises TNF-alpha. Several clinical study have shown that etanercept reduces disease activity in patients with spondyloarthropathies, including reactive arthritis and AS (4-8). Similar results have been reported with infliximab, a chimeric monoclonal antibody against TNF (915).

The aim of the present work was to compare the efficacy and safety of both etanercept and infliximab in patients with ankylosing spondylitis in a two-year open label randomised study.

\section{Patients and Methods}

Fifty consecutive patients that fulfilled the modified New York criteria for the diagnosis of AS (16) were enrolled in the study. Patients had to be non responder to oral non steroidal anti inflammatory drugs and naïve for DMARDs or other TNF blocking agents. Patients with complete ankylosis (fusion) of the spine were excluded. Approval from an independent ethics committee was obtained, and all patients provided written informed consent to participate. Patients were randomised to receive alternatively etanercept or infliximab with a ratio of 1:1. Efficacy and safety evaluations were performed at weeks 2, 4, 8, and 12 and then every 3 months until 2 years. Criteria for inclusion were: active disease for at least three months, a BASDAI $>4$ and a VAS for spinal pain score $>4$.

Patients received Etanercept at a $50 \mathrm{mg}$ dose delivered subcutaneously weekly or Infliximab at 5 $\mathrm{mg} / \mathrm{Kg}$ at week $0,2,6$ and every 6 weeks for a period of 102 weeks. The clinical response to etanercept or infliximab was evaluated on the basis of response criteria recommended by the ASAS Working Group (17). An ASAS 20 and 40 responder was defined as a patient who showed at least $20 \%$ or $40 \%$ improvement from baseline and had an absolute improvement from baseline of at least 1 unit (on a scale of $0-10$ ) in at least 3 of the following 4 assessment domains: patient's global assessment, spinal pain, function according to the Bath Ankylosing Spondylitis Functional Index (BASFI), and morning stiffness (the average of the last 2 questions of the BASDAI)

Disease activity was assessed bay the Bath Ankylosing Spondylitis Activity Index (BASDAI). Functional impairment was assessed by the 10 item Bath Ankylosing Spondylitis Functional Index (BASFI). The BASMI is an aggregate score (ranging from 0 to 10) of patient mobility assessments, including tragus-to-wall lumbar flexion (Schober test), cervical rotation, lumbar side flexion, and intermalleolar distance $(18,19)$. Chest expansion is the difference between the circumference of the chest in maximal inspiration and that in maximal expiration.

Patients were monitored for adverse events and abnormal laboratory test results over the course of the study. Vital signs were monitored, and standard haematology, serum chemistry, and urine analysis tests were evaluated.

\section{Statistics}

To compare mean differences between time points (week 0 vs week 12, week 54 and week 104), a unpaired t-test was applied. In the case of skewed distributions [CRP and erythrocyte sedimentation 
rate (ESR)] the corresponding non-parametric test (Wilcoxon test) was used. McNemar test was applied in the case of proportions

\section{Results}

A total of 50 patients were enrolled in the study; 25 were assigned to receive etanercept and 25 were assigned to infliximab. The average age of patients was $32.2 \pm 8$ years. 39 patients were male (79\%) and the duration of symptoms was $15.6+/-8.7$ years. The treatment groups had similar baseline disease activity scores and demographic characteristics (Table I). No patients discontinued therapies. Although the difference was not statistically significant, more Infliximab patients than Etanercept patients responded at the ASAS 20 level as early as week 2 but sustained differences were not evident up to week 12. After 12 weeks, 19 of 25 patients $(75 \%)$ in the infliximab group were ASAS 20 responders compared with 15 of 25 patients $(60 \%)$ in the etanercept group (Fig. 1). At the 12th week $55 \%$ of patient treated with infliximab and $43 \%$ of patients treated with etanercept were at the ASAS 40 level (fig. 1). At week 12 more infliximab than etanercept treated patients achieved a significantly reduction of BASDAI $(4.8$ vs $5.9 ; \mathrm{p}<0.005$ and 3.5 vs 5.6 ; $\mathrm{p}<$ 0.005) (fig 2), and of BASFI (3.5 vs 5; p < 0.005 ) (fig 3). Acute phase reactants, BASMI, SP and HAQ significantly decreased in both group of patients from baseline during the observation period without differences between the two groups (not shown). Treatments were generally well tolerated and adverse events were mostly mild to moderate (Table 2). There were no discontinuations for safety reasons. In particular there was no cases of opportunistic infections, tuberculosis, congestive heart disease, demyelinating disorders, lupus-like syndromes and malignancy.

\section{Discussion}

TNF blocking agents are internationally considered to represent a major progress in the treatment of AS. Comparative studies with etanercept and infliximab treatments were not yet published, however. A $50 \mathrm{mg}$ dose of etanercept delivered subcutaneously weekly and 6 weeks infusion of infliximab $(5 \mathrm{mg} / \mathrm{kg})$ produced rapid, significant, and sustained improvement in multiple clinical and laboratory measures of AS. Although no significant differences were observed at the end of the study, our results are consistent with a significant more rapid clinical improvement in the infliximab treated group. At week 12 in fact more infliximab than etanercept treated patients achieved a significantly reduction of BASDAI and BASFI, and there were also more responders in the infliximab group at the ASAS 20 and ASAS 40 level.

In general, improvements with both therapies were observed at two weeks and were sustained up to the end of observation. The potential interest of our study was also that patients enrolled in our study were outpatients that have to be considered at community levels.

CRP levels and ESR values significantly decreased and spinal mobility, as measured by Schober's test, significantly improved in patients undergoing both treatments.

The results of this randomised study suggest that treatment with both etanercept and infliximab are effective, safe, and well tolerated in patients with AS. Patients with AS, in fact, were treated continuously and we did not observed any reduction in efficacy with both treatments. 


\section{References}

1) Khan MA. Update on spondyloarthropathies. Ann Intern Med 2002;135:896-907.

2) Zochling J, van der Heijde D, Dougados M, et al. Current evidence for the management of ankylosing spondylitis: systematic literature review for the ASAS/EULAR management recommendations in ankylosing spondylitis. Ann Rheum Dis. 2006;65:423-32

3) Rudwaleit M, Hohler T. Cytokine gene polymorphisms relevant for the spondyloarthropathies. Curr Opin Rheumatol 2001;13:250-4

4) Davis JC, van der Heijde DM, J Braun et al. Efficacy and safety of up to 192 weeks of etanercept therapy in patients with ankylosing spondylitis. Ann Rheum Dis 2008;67:346-352

5) Brandt J, Khariouzov A, Listing J, Haibel H, et al. Six-Month Results of a Double-Blind, Placebo-Controlled Trial of Etanercept Treatment in Patients With Active Ankylosing Spondylitis. Arthritis Rheum 2003; 48: 1667-75

6) Davis JC, van der Heijde DM, Braun J, et al. Recombinant Human Tumor Necrosis Factor Receptor (Etanercept) for Treating Ankylosing Spondylitis. Arthritis Rheum 2003; 48: 3230-36

7) Calin A, Dijkmans BAC, Emery P, et al. Outcomes of a multicentre randomised clinical trial of etanercept to treat ankylosing spondylitis. Ann Rheum Dis 2004;63:1594-1600

8) Brandt $\mathrm{J}$, Listing $\mathrm{J}$, Haibel $\mathrm{H}$ et al. Long-term efficacy and safety of etanercept after readministration in patients with active ankylosing spondylitis. Rheumatology 2005;44:342348

9) Braun J, Brandt J, Listing J, et al. Treatment of active ankylosing spondylitis with infliximab: a randomised controlled multicentre trial. Lancet 2002; 359: 1187-93

10) Braun J, Brandt J, Listing J, et al. Two year maintenance of efficacy and safety of infliximab in the treatment of ankylosing spondylitis. Ann Rheum Dis 2005;64:229-234

11) van der Heijde D, Dijkmans B, Geusens P, et al. Efficacy and Safety of Infliximab in Patients With Ankylosing Spondylitis. Arthritis Rheum 2005; 52: 582-591

12) Marzo-Ortega $\mathrm{H}$, McGonagle $\mathrm{D}$, Jarrett $\mathrm{S}$, et al. Infliximab in combination with methotrexate in active ankylosing spondylitis: a clinical and imaging study. Ann Rheum Dis 2005;64;15681575

13) Braun J, Brandt J, Listing J et al. Long-Term efficacy and safety of infliximab in the treatment of ankylosing spondylitis. Arthritis Rheum 2003; 48: 2224-2233 
14) Braun J, Landewé R, Hermann KGA, et al. Major reduction in spinal inflammation in patients with ankylosing spondylitis after treatment with infliximab. Results of a multicenter, randomized, double-blind, placebo-controlled magnetic resonance imaging study. Arthritis Rheum 2006; 54: 1646-1652

15)Hochberg MC, Lebwohl MG, Plevy SE, Hobbs KF, Yocum DE. The benefit/risk profile of TNF-blocking agents: findings of a consensus panel. Semin Arthritis Rheum 2005; 34:819-36.

16) Van der Linden S, Valkenburg HA, Cats A. Evaluation of diagnostic criteria for ankylosing spondylitis: a proposal for modification of the New York criteria. Arthritis Rheum 1984; 27: $361-68$.

17) Anderson JJ, Baron G, van der Heijde D, Felson DT, Dougados M. Ankylosing Spondylitis Assessment Group preliminary definition of short-term improvement in ankylosing spondylitis. Arthritis Rheum 2001;44:1876-86.

18) Jenkinson TR, Mallorie PA, Whitelock HC, Kennedy LG, Garrett SL, Calin A. Defining spinal mobility in ankylosing spondylitis (AS): the Bath AS Metrology Index. J Rheumatol 1994;21:1694-8.

19)Fernández-Sueiro JL, Willisch A, Pértega-Díaz S et al. Evaluation of ankylosing spondylitis spinal mobility measurements in the assessment of spinal involvement in psoriatic arthritis. Arthritis Rheum. 2009 Mar 15;61(3):386-92 
Table 1 Baseline characteristics of patients

\begin{tabular}{|l|c|c|c|}
\hline Baseline characteristics & \multicolumn{2}{|c|}{ Treatment groups } & $p$ \\
\hline & Infliximab (n=25) & Etanercept (n=25) & \\
\hline Age (mean \pm SD) & $31.9 \pm 9.2$ & $32.6 \pm 6.8$ & NS \\
\hline Sex, M/F & $19 / 6$ & $20 / 5$ & NS \\
\hline Duration of AS, years (mean \pm SD) & $15.4 \pm 10.6$ & $15.7 \pm 6.5$ & NS \\
\hline HLA-B27 positive (\%) & $23(92)$ & $6.6 \pm 1.1$ & NS \\
\hline BASDAI score, 0-10 (mean \pm SD) & $6.5 \pm 1.2$ & $6.5 \pm 1.1$ & NS \\
\hline BASFI score, 0-10 (mean \pm SD) & $6.1 \pm 0.9$ & $3.9 \pm 1.7$ & NS \\
\hline BASMI score, 0-10 (mean \pm SD) & $3.7 \pm 1.6$ & $3.1 \pm 0.9$ & NS \\
\hline Chest expansion, cm (mean \pm SD) & $2.9 \pm 0.8$ & $6.3 \pm 1.2$ & NS \\
\hline Spinal Pain, 0-10 (mean \pm SD) & $6.0 \pm 1.5$ & $6.7 \pm 1.4$ & NS \\
\hline Patient's global assessment, 0-10 VAS & $6.4 \pm 1.4$ & $22.9 \pm 10.5$ & NS \\
\hline CRP level, mg/l (mean \pm SD) & $25 \pm 12.1$ & $32.1 \pm 14.6$ & \\
\hline ESR mm/1h (mean \pm SD) & $1.5 \pm 0.5$ & & \\
\hline HAQ (mean \pm SD) & & & \\
\hline
\end{tabular}


Table 2 No (\%) of Adverse Events (AE) through week 104

\begin{tabular}{|l|c|c|c|}
\hline AE & $\begin{array}{c}\text { Infliximab } \\
\mathrm{n}(\%)\end{array}$ & $\begin{array}{c}\text { Etanercept } \\
\mathrm{n}(\%)\end{array}$ & $\mathrm{p}$ \\
\hline Injection site reactions & $1(4)$ & $5(25)$ & $<0.005$ \\
\hline Infusion reactions & & & \\
\hline Headache & $8(32)$ & $7(28)$ & $\mathrm{NS}$ \\
\hline Diarrhea & $2(8)$ & $1(4)$ & $\mathrm{NS}$ \\
\hline Tachycardia & $12(48)$ & $8(32)$ & $\mathrm{NS}$ \\
\hline Hypertension & $4(16)$ & $2(8)$ & $\mathrm{NS}$ \\
\hline Abdominal pain & $1(4)$ & $1(4)$ & $\mathrm{NS}$ \\
\hline Uveitis & $1(4)$ & $2(8)$ & $\mathrm{NS}$ \\
\hline Optic neuritis & $1(4)$ & $1(4)$ & $\mathrm{NS}$ \\
\hline Arthralgia & $4(16)$ & $3(12)$ & $\mathrm{NS}$ \\
\hline Vertigo & $1(4)$ & $2(8)$ & $\mathrm{NS}$ \\
\hline Severe infections & $2(8)$ & $1(4)$ & $\mathrm{NS}$ \\
\hline
\end{tabular}


Fig. 1

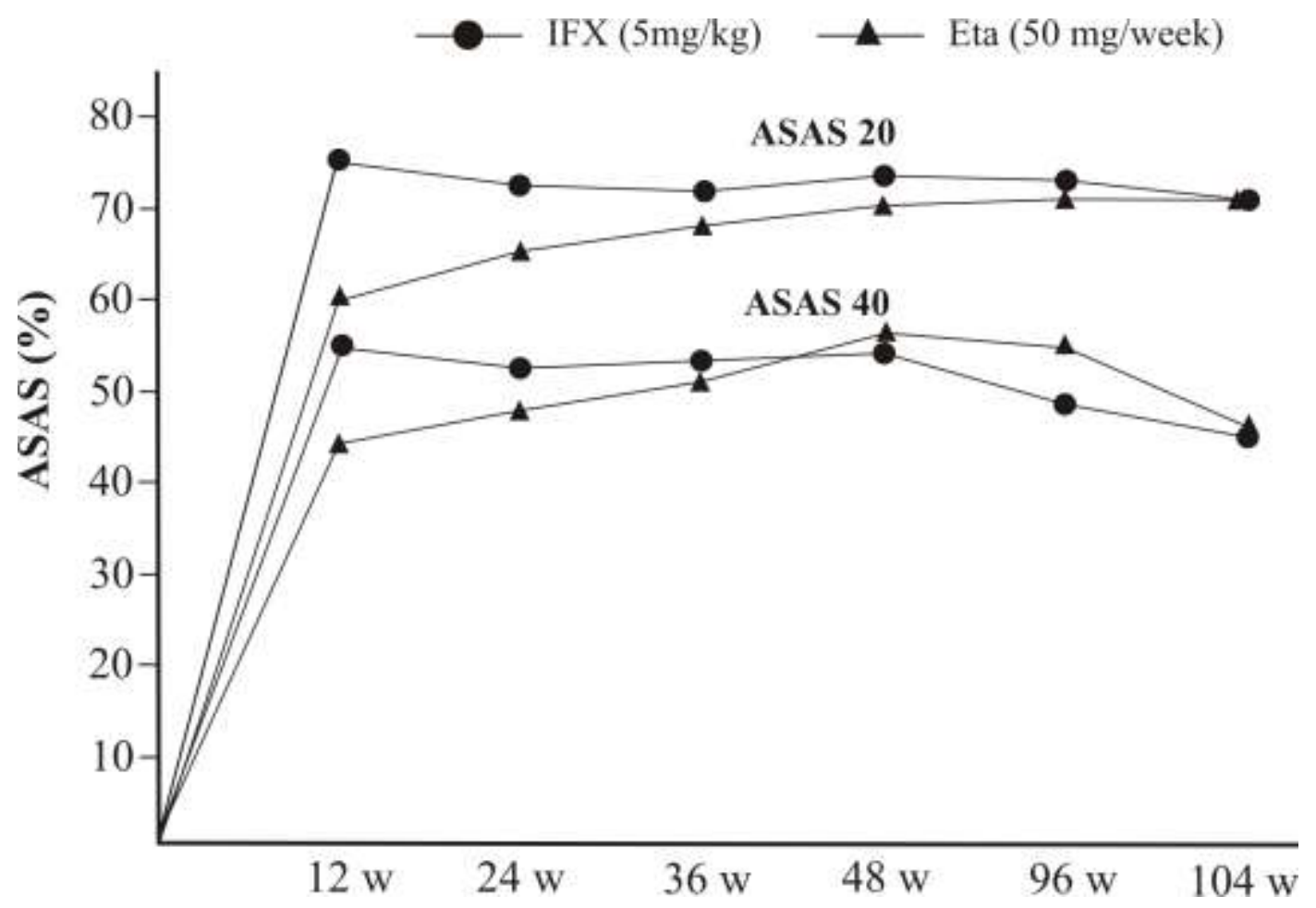


Fig. 2

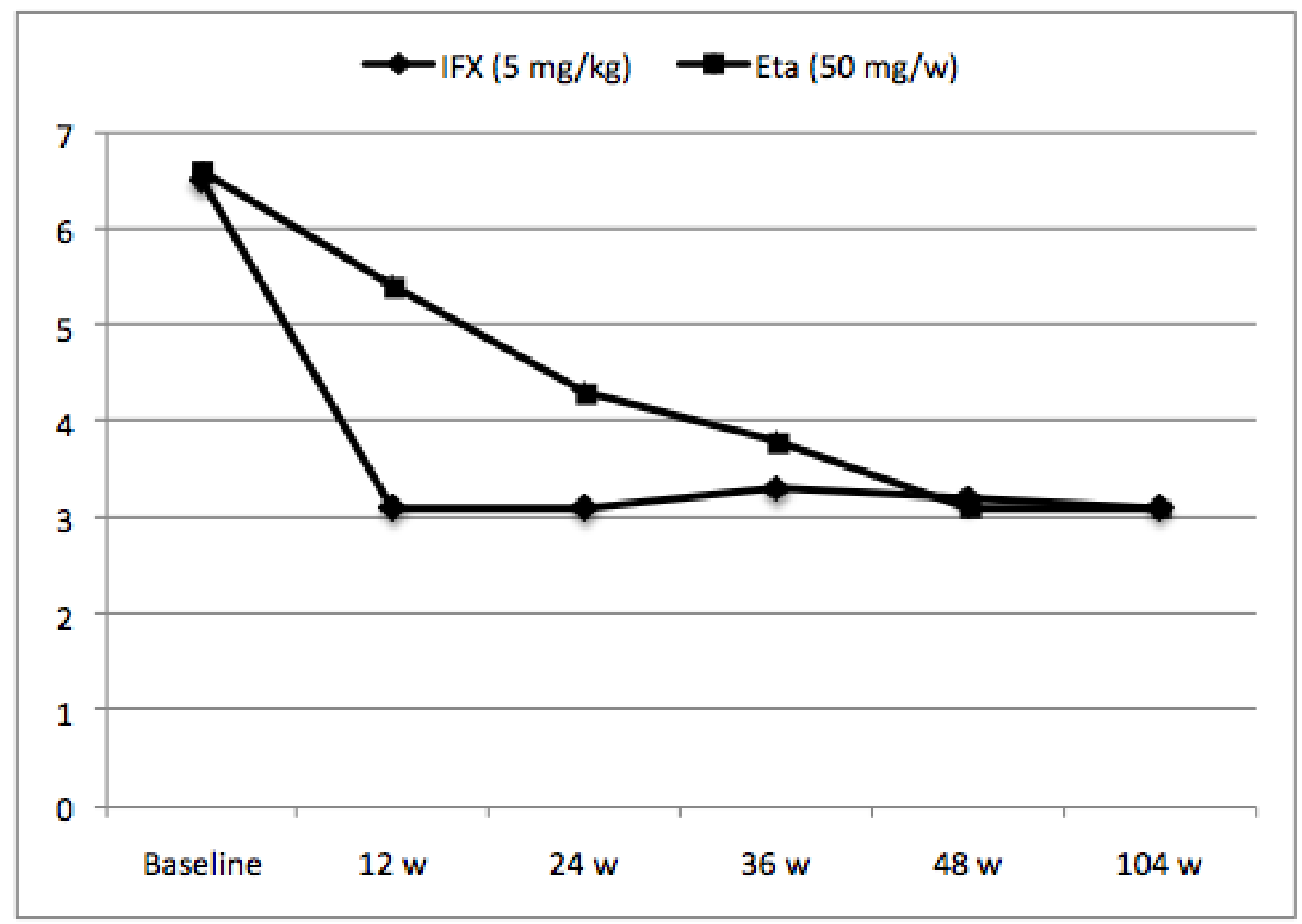


Fig. 3

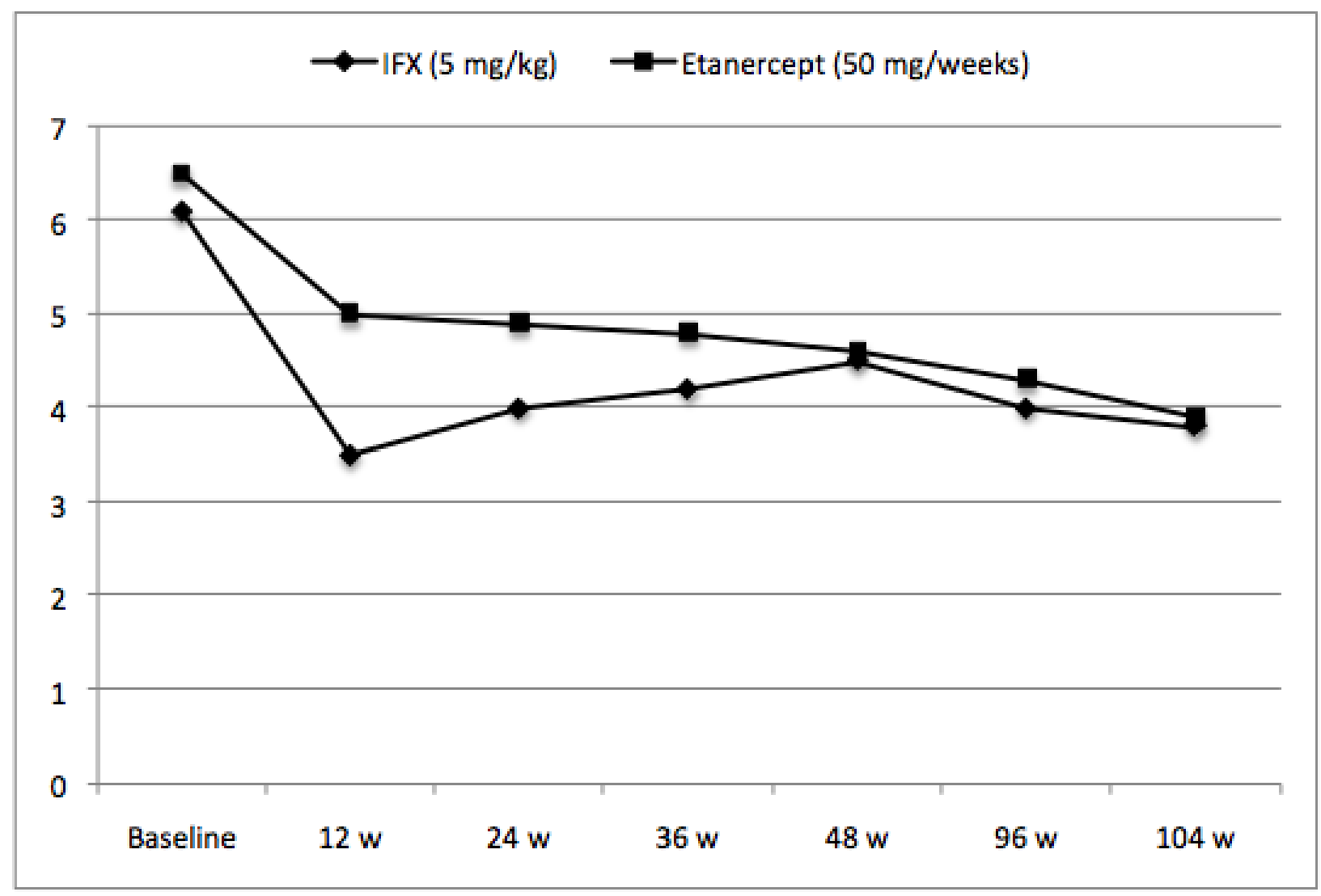




\section{Legend to figures}

\section{Figure 1}

ASAS 20 and ASAS 40 response during a two-year follow up. Circles indicate patients treated with infliximab. Triangles indicate patients treated with etanercept. Although morte infliximab treated patients reacted an ASAS 20-40 response at the $12^{\text {th }}$ week the difference was not statistically significant.

\section{Figure 2}

BASDAI lebvels in patients trated with infliximab or etanercept at $12 \mathrm{w}$ a significant decrease of BASDAI was obtained in patients treated with infliximab $(\mathrm{p}<0.005)$

Figure 3

BASFI levels in patients trated with infliximab or etanercept, at $12 \mathrm{w}$ a significant decrease of BASFI was obtained in patients treated with infliximab $(\mathrm{p}<0.005)$

Fig. 1 


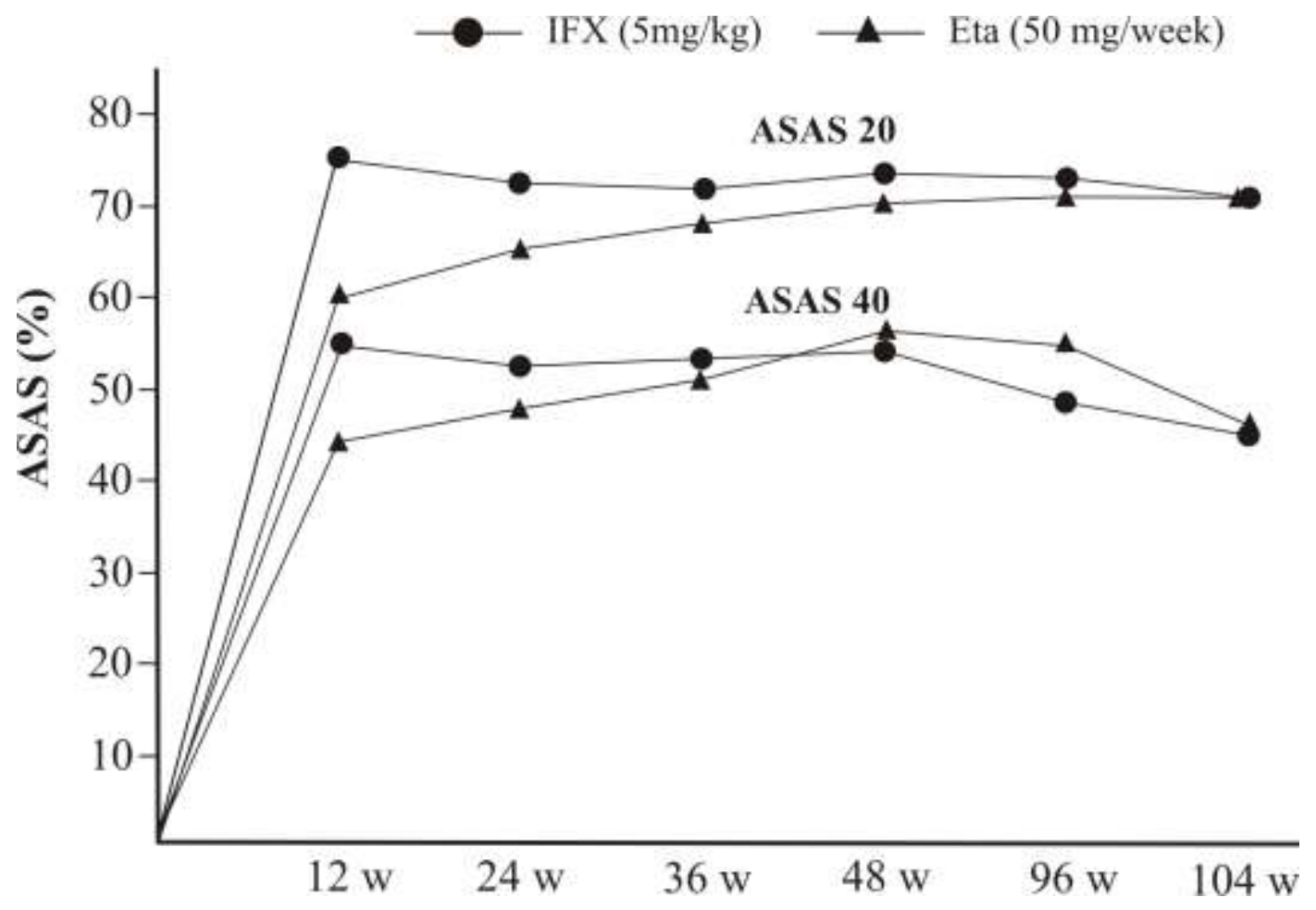

Fig. 2 


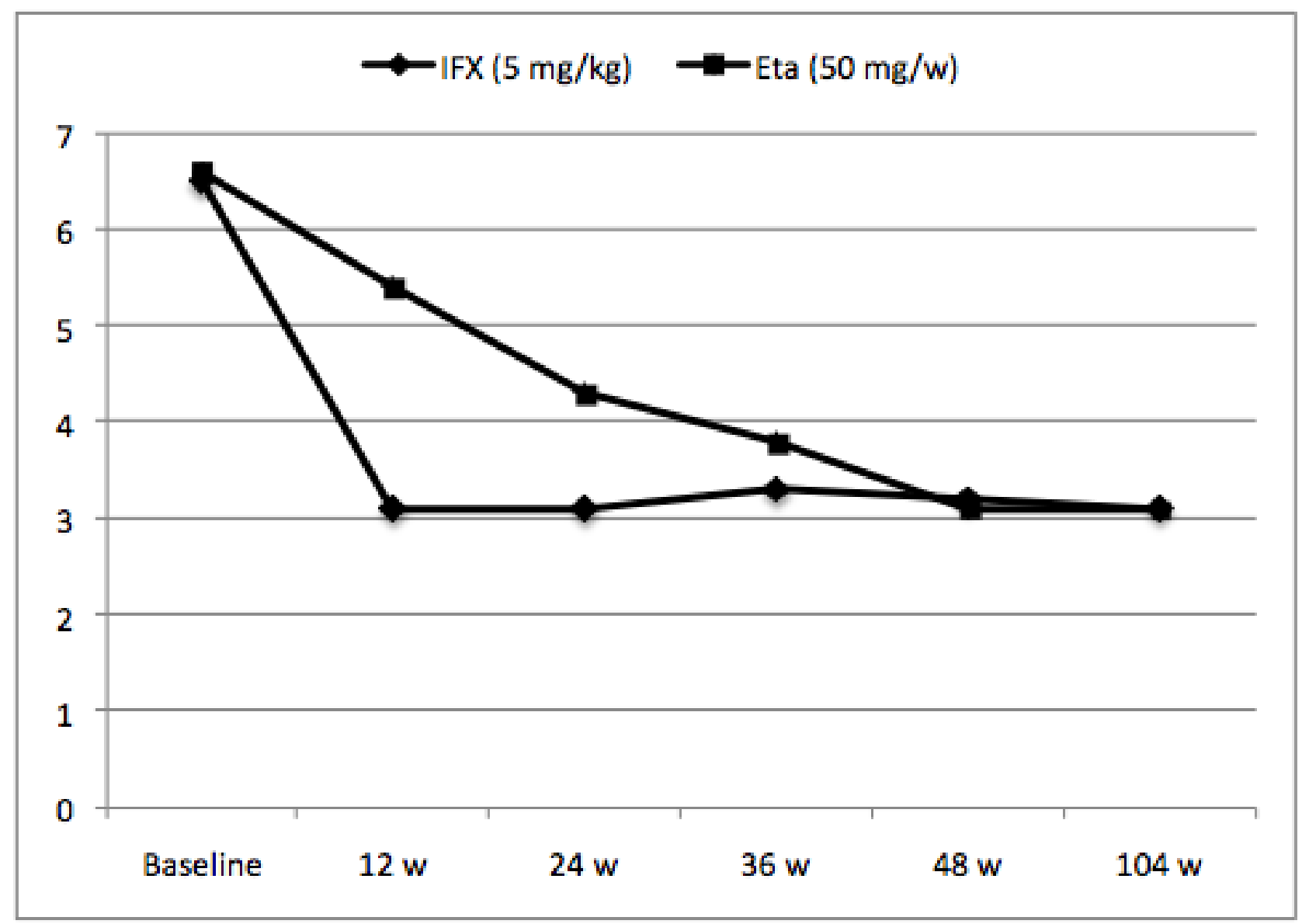

Fig. 3 


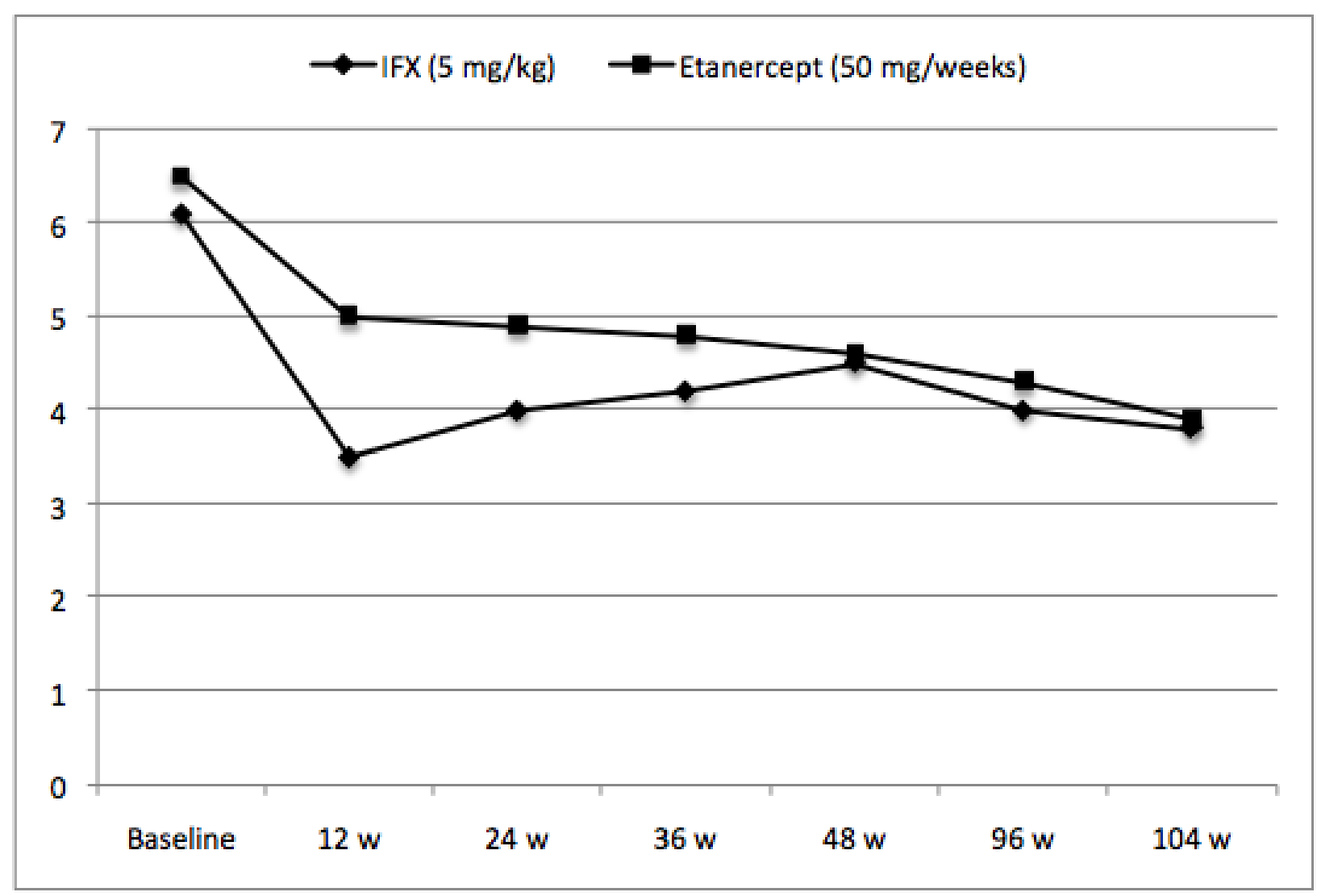


Table 1 Baseline characteristics of patients

\begin{tabular}{|l|c|c|c|}
\hline Baseline characteristics & \multicolumn{2}{|c|}{ Treatment groups } & $p$ \\
\hline & Infliximab (n=25) & Etanercept (n=25) & \\
\hline Age (mean \pm SD) & $31.9 \pm 9.2$ & $32.6 \pm 6.8$ & NS \\
\hline Sex, M/F & $19 / 6$ & $20 / 5$ & NS \\
\hline Duration of AS, years (mean \pm SD) & $15.4 \pm 10.6$ & $15.7 \pm 6.5$ & NS \\
\hline HLA-B27 positive (\%) & $23(92)$ & $6.6 \pm 1.1$ & NS \\
\hline BASDAI score, 0-10 (mean \pm SD) & $6.5 \pm 1.2$ & $6.5 \pm 1.1$ & NS \\
\hline BASFI score, 0-10 (mean \pm SD) & $6.1 \pm 0.9$ & $3.9 \pm 1.7$ & NS \\
\hline BASMI score, 0-10 (mean \pm SD) & $3.7 \pm 1.6$ & $3.1 \pm 0.9$ & NS \\
\hline Chest expansion, cm (mean \pm SD) & $2.9 \pm 0.8$ & $6.3 \pm 1.2$ & NS \\
\hline Spinal Pain, 0-10 (mean \pm SD) & $6.0 \pm 1.5$ & $6.7 \pm 1.4$ & NS \\
\hline Patient's global assessment, 0-10 VAS & $6.4 \pm 1.4$ & $22.9 \pm 10.5$ & NS \\
\hline CRP level, mg/l (mean \pm SD) & $25 \pm 12.1$ & $32.1 \pm 14.6$ & \\
\hline ESR mm/1h (mean \pm SD) & $1.5 \pm 0.5$ & & \\
\hline HAQ (mean \pm SD) & & & \\
\hline
\end{tabular}


Table 2 No (\%) of Adverse Events (AE) through week 104

\begin{tabular}{|l|c|c|c|}
\hline AE & $\begin{array}{c}\text { Infliximab } \\
\mathrm{n}(\%)\end{array}$ & $\begin{array}{c}\text { Etanercept } \\
\mathrm{n}(\%)\end{array}$ & $\mathrm{p}$ \\
\hline Injection site reactions & $1(4)$ & $5(25)$ & $<0.005$ \\
\hline Infusion reactions & & & \\
\hline Headache & $8(32)$ & $7(28)$ & $\mathrm{NS}$ \\
\hline Diarrhea & $2(8)$ & $1(4)$ & $\mathrm{NS}$ \\
\hline Tachycardia & $12(48)$ & $8(32)$ & $\mathrm{NS}$ \\
\hline Hypertension & $4(16)$ & $2(8)$ & $\mathrm{NS}$ \\
\hline Abdominal pain & $1(4)$ & $1(4)$ & $\mathrm{NS}$ \\
\hline Uveitis & $1(4)$ & $2(8)$ & $\mathrm{NS}$ \\
\hline Optic neuritis & $1(4)$ & $1(4)$ & $\mathrm{NS}$ \\
\hline Arthralgia & $4(16)$ & $3(12)$ & $\mathrm{NS}$ \\
\hline Vertigo & $1(4)$ & $2(8)$ & $\mathrm{NS}$ \\
\hline Severe infections & $2(8)$ & $1(4)$ & $\mathrm{NS}$ \\
\hline
\end{tabular}

